\title{
Eksplorasi Fungi Endofit Umbi Lapis Bawang Merah (Allium cepa) sebagai Antifungi dan Antikolesterol
}

\section{Antifungal and Anticholesterol activities of Endophytic Fungi Isolated from Allium cepa}

\begin{tabular}{l} 
Nur Amalia \\
Choironi*, \\
Sunarto, \\
Hanif Nasiatul \\
Baroroh \\
Jurusan Farmasi, \\
Universitas Jenderal \\
Soedirman, Purwokerto. \\
n.a.choironi@gmail.com \\
Kata kunci: Allium cepa, \\
fungi endofit, antifungi, \\
antikolesterol \\
\hline Keywords: Allium cepa, \\
endophytic fungi, \\
antifungal, \\
anticholesterol
\end{tabular}

Fungi endofit berpotensi sebagai alternatif pengobatan karena menghasilkan senyawa yang sama dengan tumbuhan inangnya. Allium cepa memiliki manfaat sebagai antifungi dan antikolesterol. Tujuan penelitian ini adalah isolasi, identifikasi, serta melakukan uji antifungi dan antikolesterol. Isolat yang diperoleh diidentifikasi secara makroskopik dan mikroskopik.

Metode uji antifungi terhadap Candida albicans adalah metode difusi agar dan metode uji antikolesterol menggunakan rancangan acak lengkap (pre and posttest control design). Hasil isolasi fungi endofit diperoleh isolat FEAC 1 dan FEAC 2.

Hasil penelitian menunjukkan bahwa FEAC 2 memiliki zona hambat sebesar 7,389 mm dan menurunkan kolesterol total secara signifikan serta meningkatkan kolesterol HDL.

\footnotetext{
Endophytic fungi is potential source because produces the same compound with their host plants. The purpose of this study were the isolation, identification, assay of antifungal and anti-cholesterol activity of isolat of endophytic fungi Alium cepa. Isolates were identified macroscopically and microscopically. The isolates of endophytic fungi were assay by antifungal activity with diffusion method and anti-cholesterol activity assay using completely randomized design. Isolates of endophytic fungi showed two colony were FEAC 1 and FEAC 2. This study showed that the FEAC 2 was inhibitCandida albicans $(7.389 \mathrm{~mm})$ and decrease of total cholesterol significantly and increase of HDL cholesterol.
} 


\section{Pendahuluan}

Fungi endofit merupakan fungi yang hidup bersimbiosis dalam jaringan tumbuhan inangnya dan mampu menghasilkan beberapa senyawa metabolit sekunder fungsional (Rodriguez et al., 2009; Liu et al., 2010).Beberapa fungi dengan strain yang sama berhasil diisolasi dari beberapa bagian yang berbeda dari satu tumbuhan inang, sesuai dengan kemampuannya untuk memanfaatkan medium yang ada. Metabolit sekunder isolat fungi endofit yang sama dengan inangnya, telah banyak dilaporkan memiliki berbagai aktivitas biologis antibakteri, antifungi, antioksidan dan inhibitor $\alpha$-amilase(Aly et al., 2011; Joseph, 2011).Margiono (2008) melaporkan bahwa isolat jamur endofit Syzigium aqueum dan Artocarpus heterophyllusmampu memproduksi antibiotik yang dapatmenghambat $B$. subtilis dan $F$. oxysporumf.sp. licopersicae. Abdulmyanova et al. (2016) juga melaporkan bahwa jamur endofit yang diisolasi dari Allium sativum memiliki efek penghambatan pada fitopatogenRhizoctonia solani dan Botrytis cinerea. Desmukh et al. (2018) menyatakan bahwa Xylaria sp. merupakan salah satu jenis fungi endofit yang memiliki sembilan senyawa sesquiterpen dan tiga senyawa diterpen. Senyawa sesquiterpen tersebut diketahui menghambat $C$. albicans dan $H$. compactum dengan nilai MIC 32-256 ppm. Sedangkan senyawa diterpen dapat menghambat $C$. albicans, $A$. niger, P.oryzae, $F$. avenaceum dan $H$. compactum dengan nilai MIC 16-256 ppm. Asam helmintosporal yang berasal dari fungi endofit $C$. specious memiliki aktivitas inhibitor kolesterolasiltransferase pada mikrosom hati tikus (Qader et al., 2017).

Bawang merah mengandung senyawa kuersetin pektin alil propil disulfida dan allisin yang bersifat hipoglikemik (Jaelani, 2007). Richardo et al (2001) melaporkan bahwa quersetin dapat menigkatkan kolesterol HDL serta menurunkan kolesterol LDL dan trigliserida, sedangkan allisin meningkatkan kadar kolesterol HDL pada tikus hiperkolesterolemia (Elmahdi et al, 2008). Beberapa penelitian melaporkan bahwa allisin memiliki sifat antibakteri, antifungi terhadap mikroba patogen manusia (Pyun dan Shin, 2014; Amin dan Kapadnis, 2005; Skerget et al, 2009; Benmalek et al, 2013).

Kemampuan fungi endofit menghasilkan metabolit sekunder merupakan peluang untuk mengembangkan sumber senyawa bioaktif. Penelitian ini bertujuan untuk mengisolasi fungi endofit dari umbi bawang merah (Allium cepa) sebagai antifungi dan antikolesterol.

\section{Bahan dan Metode}

\section{Isolasi Fungi endofit}

Umbi bawang merah diperoleh di daerah Brebes Jawa Tengah. Umbi bawang merah dipotong sepanjang $1 \mathrm{~cm}$. Terhadap potongan tersebut dilakukan sterilisasi permukaan dengan merendam di dalam larutan etanol $70 \%$ selama 2 menit, diikuti dengan merendam dalam $\mathrm{NaOCl} 1 \%$ selama 2 menit dan aquades steril selama 2 menit. Inokulasi dilakukan dengan cara meletakkan umbi bawang merah pada medium PDA (Potato Dextrose Agar). Inkubasi dilakukan selama 7 hari. Koloni fungi diisolasi menggunakan ose dan diletakkan pada medium PDB (Potato Dextrose Broth) (Hidayahti, 2010).

Isolat fungi endofit ditumbuhkan dalam medium PDB, diinkubasi selama 5 hari pada suhu $30{ }^{\circ} \mathrm{C}$ menggunakan shaker incubator dengan kecepatan 150 rpm. Sel dipisahkan dengan sentrifugasi 
pada kecepatan $3000 \mathrm{rpm}$ selama 15 menit. Supernatan dipisahkan dan digunakan untuk uji antifungi dan uji antikolesterol (Melliawati dan Harni, 2009 ; Noverita et al., 2009).

\section{Identifikasi Isolat Fungi Endofit}

Fungi endofit yang diperoleh diidentifikasi secara makroskopik untuk menentukan ciri-ciri morfologinya, yaitu bentuk dan warna koloni. Identifikasi secara mikroskopik menggunakan mikroskop binokuler untuk melihat morfologi sel endofit.

\section{Uji Aktivitas Antifungi terhadap Candida albicans}

Uji antifungi menggunakan metode paper disc diffusion, yaitu dengan merendam paper disc dalam supernatan kultur fungi endofit dan diletakkan pada medium MHA (Muller Hinton Agar) yang ditumbuhi fungi Candida albicans. Inkubasi dilakukan pada suhu $37{ }^{\circ} \mathrm{C}$ selama 24 jam. Aktivitas antifungi ditunjukkan dengan adanya zona jernih disekitar paper disc (Jawetz et al, 1986).

\section{Uji Aktivitas Antikolesterol}

Hewan uji yang digunakan adalah tikus putih jantan galur wistar berumur 2 bulan, dengan berat badan 150-200 g. Penelitian menggunakan rancangan acak lengkap. Dua puluh empat tikus dibagi menjadi 4 kelompok secara acak dan diadaptasikan terlebih dahulu selama 2 minggu. Pemberian pakan diet tinggi lemak dilakukan selama penelitian. Pemberian fungi endofit dilakukan selama 2 minggu pada hari ke-8 sampai dengan hari ke-21. Pembagian kelompok hewan uji sebagai berikut :

1) Kelompok I: kelompok kontrol negatif (pakan diet tinggi lemak + aquades p.o)

2) Kelompok II: kelompok kontrol positif (pakan diet tinggi lemak
+ Atorvastatin dosis $0,9 \mathrm{mg} / \mathrm{kg}$ BB/hari p.o)

3) Kelompok III: kelompok perlakuan (pakan diet tinggi lemak + FEAC 1 12,5 ml/kg $\mathrm{BB} /$ hari p.o)

4) Kelompok IV: kelompok perlakuan (pakan diet tinggi lemak + FEAC 2 12,5 $\mathrm{ml} / \mathrm{kg}$ $\mathrm{BB} /$ hari p.o)

Analisis dilakukan secara kuantitatif dengan pengukuran kadar kolesterol darah tikus masing-masing kelompok pada hari ke-0, hari ke-8 dan hari ke-21. Analisis normalitas menggunakan uji statistik.

\section{Hasil dan Pembahasan}

Umbi bawang merah ditumbuhkan dalam medium PDA dengan penambahan antibiotik amoxicillin 2\% untuk mencegah pertumbuhan bakteri dalam medium. Fungi endofit yang tumbuh disekitar umbi diisolasi dan dikultivasi menggunakan medium PDB. Jalgonwala et al (2011) menyatakan bahwa setiap sel inang dapat menghasilkan jenis isolat fungi endofit yang berbeda dan bervariasi karena merupakan mekanisme adaptasi terhadap mikroekologi serta kondisi fisiologis yang spesifik dari masingmasing tumbuhan inang. Hasil penelitian menunjukkan adanya 2 jenis fungi endofit yaitu FEAC1 dan FEAC2.

PDB merupakan medium untuk memicu pertumbuhan dan menghasilkan metabolit mikroba masing-masing isolat. Joseph et al, (2011) melaporkan bahwa PDB dapat digunakan untuk menjaring produksi antimikroba oleh isolat-isolat fungi endofit. Produksi antimikroba menggunakan PDB menggambarkan sumber karbon atau substrat spesifik sebagai pemicu dalam metabolisme 
substrat menjadi agensia antimikroba (Purwanto, 2011).

Identifikasi fungi endofit secara makroskopik dan mikroskopik mengacu pada buku petunjuk menurut Barnett dan Barry (1972). Hasil identifikasi fungi endofit dapat dilihat pada Tabel 1 dan Gambar 1 dan 2.

Tabel 1. Hasil identifikasi makroskopik dan mikroskopik isolat fungi endofit

\begin{tabular}{|c|c|c|}
\hline $\begin{array}{l}\text { Kode } \\
\text { Isolat }\end{array}$ & $\begin{array}{c}\text { Morfologi } \\
\text { Koloni }\end{array}$ & $\begin{array}{l}\text { Morfologi } \\
\text { Sel }\end{array}$ \\
\hline $\begin{array}{c}\text { FEAC } \\
1\end{array}$ & $\begin{array}{l}\text { - Warna koloni } \\
\text { putih } \\
\text { - Miselium } \\
\text { merambat } \\
\text { - Koloni tumbuh } \\
\text { menyebar }\end{array}$ & $\begin{array}{l}\text { - Konidia } \\
\text { berbentuk } \\
\text { bulat, hialin } \\
\text { dan tersusun } \\
\text { atas } 1 \text { sel } \\
\text { - Hifa septat } \\
\text { - Miselium } \\
\text { bercabang } \\
\text { - Konidiofor } \\
\text { panjang dan } \\
\text { tidak } \\
\text { bercabang }\end{array}$ \\
\hline $\begin{array}{c}\text { FEAC } \\
2\end{array}$ & $\begin{array}{l}\text { - Warna koloni } \\
\text { kuning } \\
\text { - Bentuk koloni } \\
\text { bulat kecil, } \\
\text { berkelompok }\end{array}$ & $\begin{array}{l}\text { - Konidia } \\
\text { berbentuk } \\
\text { ovoid, bulat } \\
\text { dan tersusun } \\
\text { atas } 1 \text { sel } \\
\text { - Hifa septat } \\
\text { - Konidiofor } \\
\text { bercabang }\end{array}$ \\
\hline
\end{tabular}

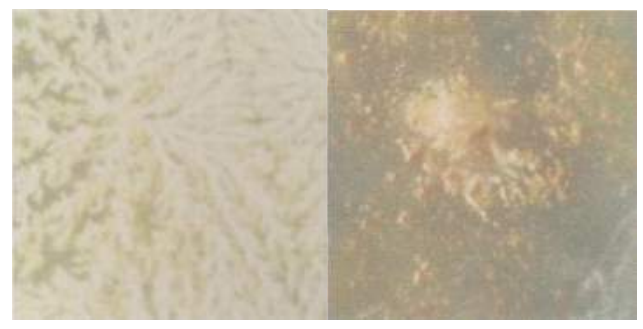

FEAC 1

FEAC 2

Gambar 1. Morfologi isolat fungi endofit

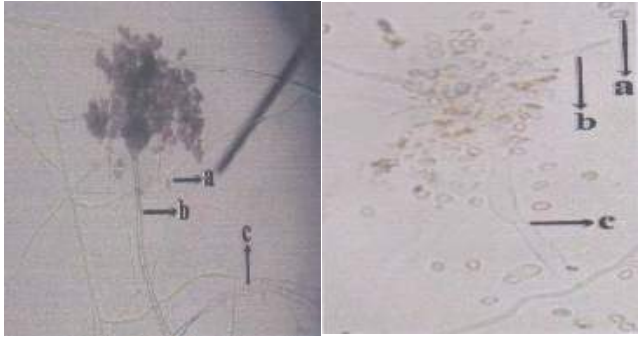

FEAC 1

FEAC 2

Keterangan: a: konidia, b: konidiofor, c: hifa

Gambar 2. Hasil pengamatan mikroskopikisolat fungi endofit

Menurut Gandjar et al (2006), identifikasi secara makroskopik dan mikroskopik memiliki kelemahan mengidentifikasi spesies baru atau fungi anamorfik karena sering ditemukan variabilitas tingkat strain. Kelemahan ini dapat diatasi dengan taksonomi modern yaitu identifikasi secara genotip yang berasal dari DNA atau RNA sel.

Uji aktivitas antifungi metode paper disc diffusion, prinsip metode ini adalah isolat fungi endofit berdifusi dari paper disc ke dalam medium MHA yang ditumbuhi $C$. albicans. Daerah jernih disekitar paper disc (zona hambat) menunjukkan bahwa isolat fungi endofit mampu menghambat pertumbuhan $C$. albicans. Hasil penelitian uji aktivitas antifungi terhadap $C$. albicans dapat dilihat pada Tabel 2.

Tabel 2. Diameter zona hambat isolat fungi endofit (10 ppm) terhadap C. albicans

\begin{tabular}{llccc}
\hline \multirow{2}{*}{$\begin{array}{l}\text { Kode } \\
\text { isolat }\end{array}$} & $\begin{array}{l}\text { Repli } \\
\text { kasi }\end{array}$ & \multicolumn{2}{l}{$\begin{array}{l}\text { Diameter } \\
\text { hambat }(\mathbf{m m})\end{array}$} & zona \\
\cline { 3 - 5 } & & 1 & 2 & 3 \\
\hline & I & 0 & 0 & 0 \\
FEAC 1 & II & 0 & 0 & 0 \\
& III & 0 & 0 & 0 \\
& Rata-rata & & & 0 \\
& I & 7,1 & 8,1 & 7,0 \\
FEAC 2 & II & 7,7 & 8,8 & 6,9
\end{tabular}




$\begin{array}{lll}\text { III } 7,0 \quad 7,0 & 6,3 \\ \text { Rata-rata } & & 7,4\end{array}$

Diameter paper disc: $6 \mathrm{~mm}$

Isolat FEAC 1 tidak dapat menghambat pertumbuhan $C$. albicans dibandingkan dengan isolat FEAC 2. FEAC 2 mampu menghasilkan metabolit sebagai antifungi.Menurut standar NCCLS (2004), sampel termasuk kategori peka terhadap fungi uji jika diameter $\geq 19 \mathrm{~mm}$, intermediet jika diameter 15-18 $\mathrm{mm}$, dan resisten jika diameter $\leq 14 \mathrm{~mm}$.Pada penelitian ini, nilai diameter zona hambat sampel termasuk dalam kategori resisten. Berdasarkan penelitian Alawiyah (2014), FEAC 2 mengandung asam tetradekanoat dan asam heksadekanoat yaitu golongan asam lemak yang memiliki aktivitas antibakteri terhadap Klebsiella pneumoniae dengan mekanisme mengganggu pembentukan energi sel pada tahap transport elektron dan fosforilasi oksidatif. Selain itu, golongan senyawa asam lemak juga mampu menghambat aktivitas enzimatik pada mikroba dan menghasilkan produk toksik yaitu peroksidase yang menyebabkan sel mikroba lisis (Desbois dan Smith, 2010; Akpuaka et al, 2013).

Uji aktivitas antikolesterol isolat fungi endofit dilihat dari kadar kolesterol total dan kolesterol HDL tikus. Hasil pengukuran kolesterol total diperoleh bahwa semua kelompok mengalami peningkatan pada hari ke-0 sampai hari ke-8 (Gambar 3). Hal ini menunjukkan bahwa pemberian pakan diet tinggi lemak selama 7 hari mampu meningkatkan kadar kolesterol total. Setelah hari ke-21 diperoleh hasil bahwa kelompok kontrol negatif terus meningkat kadar kolesterol totalnya dibandingkan dengan kelompok kontrol positif maupun kelompok perlakuan dengan isolat fungi endofit. Hasil penurunan kolesterol total kelompok perlakuan FEAC $1 \quad(9,05 \%)$ hampir sama dengan kelompok kontrol positif $(8,20 \%)$. Sedangkan penurunan kolesterol oleh FEAC 2 lebih baik dibandingkan dengan kelompok kontrol positif, yaitu $30,75 \%$. Hal tersebut didukung dengan analisa statistik yang menunjukkan bahwa isolat FEAC 2 dapat menurunkan kolesterol total pada tikus yang diberi pakan diet tinggi lemak $(p<0,05)$. Beberapa penelitian melaporkan bahwa bawang merah memiliki salah satu derivat flavonoid dalam jumlah banyak yaitu senyawa quersetin yang memiliki aktivitas menurunkan kolesterol (Leelarungrayub et al, 2006; Arai, 2000). Penelitian Casaschi et al (2002) menyatakan bahwa quersetin dapat menurunkan kadar kolesterol total dan kadar kolesterol LDL dengan mekanisme menghambat sekresi Apoliprotein B (Apo B) pada sel $\mathrm{CaCo}-2$ serta menurunkan aktivitas MTP yang berperan pada pembentukan lipoprotein dengan mengkatalis perpindahan lipid ke molekul Apo B. Penelitian lain juga menyatakan bahwa quersetin juga mampu menghambat aktivitas enzim HMG-KoA reduktase yang berperan dalam pembentukan kolesterol.

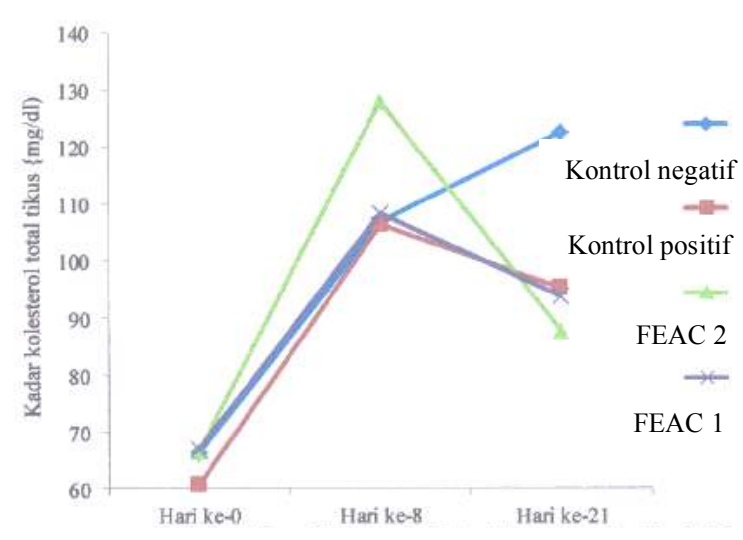

Gambar 3. Grafik kadar kolesterol total tikus hari ke- 0 , hari ke- 8 dan hari ke-21

Hasil pengukuran kadar kolesterol HDL menunjukkan bahwa semua kelompok mengalami peningkatan 
kolesterol HDL pada hari ke-0 sampai hari ke-8 (Gambar 4). Pemberian FEAC 1 tidak mampu meningkatkan kadar kolesterol HDL kelompok perlakuan dengan FEAC 1 (9,05 \%). Sedangkan hasil peningkatan kolesterol HDL oleh FEAC $2(13,88 \%)$ lebih baik dibandingkan dengan kelompok kontrol positif $(8,95 \%)$. Analisa statistik menunjukkan bahwa pemberian perlakuan pada semua kelompok tidak berpengaruh terhadap kadar kolesterol HDL tikus $(\mathrm{p}<0,05)$.

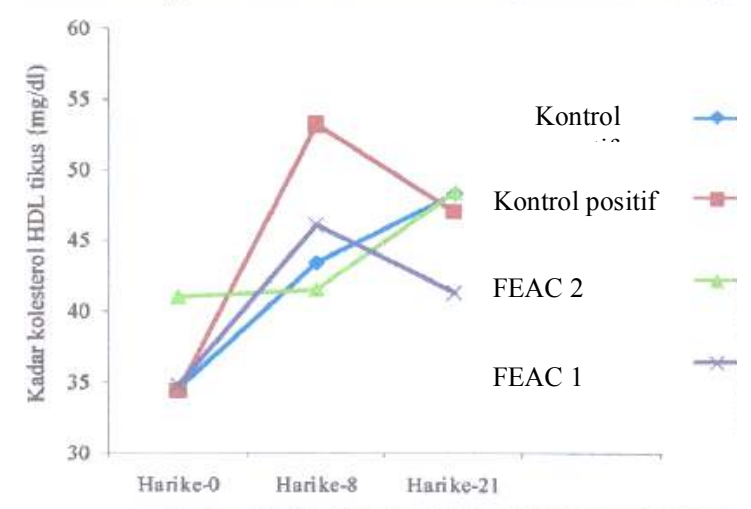

Gambar 4. Grafik kadar kolesterol HDL tikus hari ke- 0 , hari ke-8 dan hari ke-21

Berdasarkan penelitian ini menunjukkan bahwa FEAC 1 dapat menurunkan kadar kolesterol total namun tidak menunjukkan perbedaan signifikan dengan pemberian Atorvastatin serta tidak dapat meningkatkan kadar kolesterol HDL pada tikus wistar jantan. Sedangkan FEAC 2 mampu menurunkan kadar kolesterol total secara signifikan dibandingkan dengan Atorvastatin dan dapat meningkatkan kadar kolesterol HDL pada tikus wistar jantan, meskipun tidak menunjukkan perbedaan signifikan.

\section{Simpulan}

Isolat FEAC 2 memiliki aktivitas menghambat pertumbuhan fungi $C$. albicans dalam kategori resisten. Isolat tersebut juga menurunkan kadar kolesterol total secara signifikan dibandingkan Atorvastatin.

\section{Daftar Pustaka}

Abdulmyanova, L.I., Fayzieva, F.K., Ruzieva, D.M., Rasulova, G.A., Sattarova, R.S., Gulyamova, T.G., 2016, Bioactivity of Fungal Endophytes associating with Allium Plants Growing in Uzbekistan, International Journal of Current Microbiology and Applied Science, 5(9): 769-778.

Akpuaka, A., Ekwenchi, M.M., Dashak, D.A., Dildar, A., 2013, Biological Activities of Characterized Isolates of n-hexane Extract of Azadirachta Indica A. Juss (Neem) Leaves, New York Science Journal, 6(6): 119-124.

Alawiyah, S.Z., 2014, Isolat Fungi Endofit Umbi Lapis bawang Merah (Allium cepa) sebagai Antibakteri terhadap Klebsiella pneumonia, Skripsi, Fakultas Ilmu-Ilmu Kesehatan, Universitas Jenderal Soedirman, Purwokerto.

Aly, A.H., Debbab, A., and Proksch, P., 2011, Fungal Endophytes: Unique Plant Inhibitants with Great Promises, Applied Microbiology and Biotechnology, 90(6): 1829-1845.

Amin, M., Kapadnis, B.P., 2005, Heat Stable Antimicrobial Activity of Allium ascolanicum Against Bacteria and Fungi, Indian Journal Experimental Biology, 43: 751-754.

Arai, Y., Shaw, W., Mitsuru, K., Kayoko, S., Rika, M., Naohide, K., 2000, Dietary Intakes of Flavonols, Flavnes and Isoflavones by Japanese Women and The Inverse Correlation Between Quercetin Intake and Plasma LDL Cholesterol Concentration, Journal of Nutrition, 130(9): 2243-2250.

Benmalek, Y., Ouahiba, A.Y., Aicha, B., and Marie-Laure F., 2013, Antimicrobial and Antioxidant Activitie of Illicum verum, Crataegus 
oxyacantha, Monogyna sp. and Allium cepa Red and White Varieties, Bioengineered, 4(4): 244-248.

Barnett, H.L., Barry, B.H., 1972, Ilustrated Genera of Imperfect Fungi, $3^{\text {rd }}$ Edition, Burgess Publishing Company, Virginia.

Casaschi, A., Qi, W., Ka'ohimanu, D. Alison, R., Andre, T., 2002, Intestinal Apolipoprotein B Secretion is Inhibited by The Flavonoid Quercetin Potential Role of Microsomal Triglycerida Trasfer Protein and Diacylglycerol Acyltransferase, Lipids, 37(7): 647-652.

Desmukh, S.K., Gupta, M.K., Prakash, V., Saxena, S., 2018, Endophytic Fungi : A Source of Potential Antifungal Compounds, Journal of Fungi, 4(3): 1-42.

Desbois, A.P., Smith, V.J., 2010, Antibacterial Free Fatty Acid: Activities Mechanism of Action and Biotechnological Potential, Applied Microbiolology and Biotechnology, 85(6): 1629-1642.

Elmahdi, B., Maha, M., Khalil, Afaf, I., Abulgasim, 2008, The Effect of Fresh Crushed Garlic Bulbs (Allium sativum) on Plasma Lipids in Hypercholesterolemic Rats, Research Journal of Animal and Veterinary Science, 3: 15-19.

Gandjar, L., Wellyzar, S., Ariyanti, O., 2006, Mikologi Dasar dan Terapan, Fakultas Kedokteran, Universitas Indonesia, Jakarta.

Hidayahti, N., 2010, Isolasi dan Identifikasi Jamur Endofit pada Umbi Bawang Putih (Allium sativum) Sebagai Penghasil Senywa Antibakteri terhadap Bakteri Staphylococcus mutan dan Eschericia coli, Skripsi, Fakultas Sains dan Teknologi, Universitas Negeri Malang, Malang.
Jaelani, 2007, Khasiat Bawang Merah, Penerbit Kanisius, Yogyakarta.

Jalgonwala, R.E., Bhavna, V.M., Raghunath, T.M., 2011, A Review: Natural Products from Plant Associated Endophytic Fungi, Journal of Microbiology and Biotechnology Research, 1(2): 21-32.

Jawetz, E., Melnick, J.L., Adelberg, E.A., 1986, Mikrobiologi Kedokteran, diterjemahkan oleh Bonang, Edisi 20, EGC Pres, Jakarta.

Joseph, B., Priya, R.M., 2011, Bioactive Compound from Endophytes and Their Potential in Pharmaceutical Effect: A Review, American Journal of Biochemistry and Molecular Biology, 1(3): 291-309.

Leelarungrayub, N., Vibon, R., Nantaya, C., Janusz, M.G., 2006, Quantitative Evaluation of The Antioxidant Properties of Garlic and Shallot Preparations, Nutrition, 22(3): 266274.

Liu, C.; Liu, T.; Yuan, F., and Gu, Y., 2010, Isolating Endophytic Fungi from Evergreen Plants and Determining their Antifungus Activities, African Journal of Microbiology Research, 4(21): 22432248.

Margiono, S., 2008, Produksi Metabolit Sekunder (Antibiotik) oleh Isolat Jamur Endofit Indonesia, Majalah Farmasi Indonesia, 19(2): 86-94.

Melliawati, R., Harni, 2009, Senyawa Antibakteri Eschericia coli ATCC 35218 dan Staphylococcus aureus ATCC 25923 dari Kapang Endofit Taman Nasional Gunung Halimun, Jurnal Natur Indonesia, 12(1): 21-27.

National Committee for Clinical Laboratory Standards (NCCLS), 2004, Method for Antifungal Disk Diffusion Susceptibility Testing of Yeasts; Approved Guideline, NCCLS 
document M44-A Vol 24, The National Committee for Clinical Laboratory Standards, USA.

Noverita, Dinah, F., 2009, Isolasi dan Uji Aktivitas Antibakteri Jamur Endofit dari Daun dan Rimpang Zingiber otensii Val., Majalah Farmasi Indonesia, 4(4): 171-176.

Purwanto, 2011, Isolasi dan Identifikasi Senyawa Penghambat Polimerisasi Hem dari Endofit Artemisia annua, Tesis, Magister Farmasi Sains dan Teknologi, Fakultas Farmasi UGM, Yogyakarta.

Pyun, M.S., Shin, S., 2014, Antifungal Effect of The Volatile Oil from Allium Plants Against Trichophyton species and Synergism of The Oils with Ketoconazole, Phytomedicine, 13(6): 394-400.

Qader, M.M., Kumar, N.S., Jayasinghe, L., Araya, H., Fujimoto, Y., 2017, Bioactive Sesquiterpenes from An Endophytic Fungus Bipolaris Sorokiniana Isolated from A Popular Medicinal Plant Costus speciosus, Micology An International Journal on Fungal Biology, 8(1): 17-20.

Richardo, K.F.S., Oliveira, T.T.D., Nagem, T.J., Pinto, A.D.S., Oliveira, M.G.A., Soares, J.F., 2001, Effect of Flavonoids Morin, Quercetin and Nikotinic Acid on Lipid Metabolis of Rats Experimentally Fed with Triton, Brazilian Archives of Biology and Technology, 44(3): 263-267.

Rodriguez, R.J., White Jr., J.F., Arnold, A.E.,Redman, R.S., 2009, Fungal Endophytes: Diversity and Functional Roles, New Phytologist, 182(2): 1-17.

Skerget, M.L., Majhenie, M., Bezjal and Kenz, 2009, Antioxidan, Radical Scavenging and Antimicrobial Activities of Red Onion (Allium cepa L.) Skin and Edible Part Extracts, Chemical and Biochemical
Engineering Quarterly, 23(4): 435444. 